Covered in: Web of Science (WOS); EBSCO; ERIH+; Google Scholar; Index Copernicus; Ideas RePeC; Econpapers; Socionet; CEEOL; Ulrich ProQuest; Cabell, Journalseek; Scipio; Philpapers; SHERPA/ROMEO repositories; KVK; WorldCat; CrossRef; CrossCheck

2020, Volume 11, Issue 2, pages: 01-11 | https://doi.org/10.18662/po/11.2/153

\section{Towards a Post- Pandemic Postmodern Society - Is the Pandemic a Deconstruction of the Postmodern Society?}

\section{Eric GILDER ${ }^{1}$}

${ }^{1}$ Department of Communication and Development Studies, The Papua New Guinea University of Technology, Lae, Papua New Guinea.
Abstract: Under Fredric Jameson's 'late modern' capitalist system that birthed it, postmodernity has often been thought of (by both partitioners as well as critics) as a playful, not entirely serious thing. In his introductory essay on another key theorist of postmodernity, Jacques Baudrillard, Douglas Kellner states: "'Baudrillard obviously wants to have it both ways with social theorists thinking that he provides salient perspectives on contemporary social realities, that Baudrillard reveals what is really happening, that he tells it like it is. And yet more cynical anti-sociologists are encouraged to enjoy Baudrillard's fictions, his experimental discourse, his games, and his play. Likewise, he sometimes encourages cultural metaphysicians to read his work as serious reflections on the realities of our time, while winking a pataphysical aside to those skeptical of such undertakings. Thus, it is undecidable whether Baudrillard is best read as science fiction and pataphysics or as social theory."But the time for such a playful intellectual consumerism seems now as dated and out of place as a crowded high street or shopping mall.

Keywords: philosophy; philosophical trends; pandemic; postmodern society; post-pandemic society.

How to cite: Gilder, E. (2020). Towards a PostPandemic Postmodern Society - Is the Pandemic a Deconstruction of the Postmodern Society?. Postmodern Openings, 11(2), 01-11. https://doi.org/10.18662/po/11.2/153 
The kind invitation by the editors of Postmodern Openings to contribute my thoughts to this special issue (dedicated to responses by members of our academic community to the COVID-19 pandemic) has me thinking about what I can profitably say in my present state of mind about the historic, revolutionary situation we presently face. I do this with a reservation: that the crisis has caused me to (hopefully temporarily) lose my ability to think [introject coming!] clearly is an intellectual 'should'. One thing is certain -I'm not alone in this facing this thinking problem. The pandemic's apocalyptic nature of a revelation-in-process causes me (and others) to question the foundations of modernity and postmodernity.

Under Fredric Jameson's 'late modern' capitalist system that birthed it (1991), postmodernity has often been thought of (by both partitioners as well as critics) as a playful, not entirely serious thing. In his introductory essay on another key theorist of postmodernity, Jacques Baudrillard, Douglas Kellner states: ""Baudrillard obviously wants to have it both ways with social theorists thinking that he provides salient perspectives on contemporary social realities, that Baudrillard reveals what is really happening, that he tells it like it is. And yet more cynical anti-sociologists are encouraged to enjoy Baudrillard's fictions, his experimental discourse, his games, and his play. Likewise, he sometimes encourages cultural metaphysicians to read his work as serious reflections on the realities of our time, while winking a pataphysical aside to those skeptical of such undertakings. Thus, it is undecidable whether Baudrillard is best read as science fiction and pataphysics or as social theory" (2003, pp. 329-30). But the time for such a playful intellectual consumerism seems now as dated and out of place as a crowded high street or shopping mall.

In her book, Postmodernism and the Social Sciences (1992), Pauline Marie Rosenau argues (in summary) that postmodernity is a child of the humanities; positing that its playfulness is a quality being most appropriate in such an intellectual nursery. She holds that it is not so appropriate for the worldly social sciences, because "in the social sciences, research results are encrusted in power relations," and (sometimes), "they are relevant for policy making, and this is of enormous import" (p. 168). She thus argues that the outputs of the humanities do not carry this policy burden, so its corresponding lack of responsibility for its truth claims becomes an ethical concern when it aspires to such a social role. As I have mentioned to my own students, in literature having many diverse readings of Shakespeare is a good thing, indeed, the more exoteric and esoteric meanings we can see in (and out of) the text the better. Conversely, when we ask the doctor for medical diagnosis of an illness such as COVID-19, in our suffering we 
demand clear, correct and unambiguous answers. Consider a pharmacist: if he or she misreads a doctor's prescription and gives a patient the wrong medicine or amount thereof, that patient could die. Rosenau points out that humanities professors, if they are wrong in their truth claims, they do not directly affect the physical lives of their students.

In my reading, one helpful perspective that I have come across has been the work of the quintessentially modern political theorist Hannah Arendt. In The Human Condition (1998), she distinguishes between labor ('organic' functions, which are constant, never-ending; think distracting housework), work ('craft' activity, which is aimed at producing a useful product of creative and market value) (cf. Gilder, 1997) and ephemeral action (which disappear into the air unless someone works to make some record of them).

This worldwide COVID-19 pandemic calls us all (whatever our acquired personal and social identities) back to the ascribed, organic fact of that we are mortal biological creatures, with simple but inescapable primary needs for food, water, shelter, security (with physical intimate community being, however necessary for our mental and social health, a dangerous vector of disease). In recognition of such life inevitabilities, our previously multi-faceted economies have been forced to distinguish between 'essential' and 'non-essential' work, and (given the wide and deep contractions of our economies) it seems that they have been too dependent upon strictly discretionary spending, however desirable. Residing in a conceptual space betwixt 'essential' and non-essential', and being premised on close physical contact for their functioning, many schools and universities worldwide have been forced to close because of the fear of contagion. Thus. we are now asked as professors to teach our students and perform at conferences (the life-activities of our profession) by limited mediated channels. Scholars and students alike are all struggling with this fact, as we sit at home 'sheltering in place', isolated and seeking to keep our wits about us.

Speaking personally, I am a communal intellectual who thrives on sharing my ideas with others who are smarter than me, building my contributions upon (in Matthew Arnold's formulation) "the best that has been thought and said" by thinkers of previous generations (as cited by Kalantzis \& Cope, 2020). In that the last thing I'd like is to be the smartest person in the room; I am suffering now because I cannot meet my wonderful, brighter colleagues at conferences and, in Wayne Booth's words, 'co-duce' improved knowledge with them in person (1988, pp. 72-73). Over the decades I've been a professor, I have learnt so much by attending conferences; hearing, reading and conversing over dinner and drinks about 
ideas that matter to our discourse community. But what does all this highminded prose matter now in this time of crisis? What competing values do we all place upon our life, our bodily health, or upon the soundness of our sole and collective minds? Maslow's triangle (1943) stipulates the basic human needs need to be fulfilled before higher order functions can be profitably sustained. The present pandemic challenges our intellectual pretensions by reminding us, in the end, that our 'minecraft' productions so valued by a society of collective thought constructs depend upon individual bio-chemical brains sustained by vulnerable biological bodies, which, modern medicine has only recently made largely safe (at least in the developed world) (Gilder \& Hagger, 2012) ${ }^{1}$. To think clearly, philosophers have to have nourished brains, and minds free from unnecessary anxiety. Given the immediate, uncertain realties posed by a dangerous, invisible virus, I find myself with a cluttered mind, harbouring anxieties on matters beyond my control, and ignoring those matters within my control.

I thus remind myself when I tell my students of Communication Theory: in the social sciences, theories have several 'intended outcomes' (Hahn, Lippet \& Paynton, 2014). One is to understand the world around us; another is to predict and control the world around us; and another is to promote positive critical/cultural change critique in it. Pre-modernity, in my view, was primarily hermeneutical/logical, seeking understanding with limited external tools and internal logics, modernity empirical and practical, seeking to predict and control the environment around us. Postmodernity falls into the last camp, because it points to the philosophical blind spots (and august policy failures) of modernity.

The dilemma of high modernity balancing its past successes and failures as well as its projected ambiguous policy prospects was best outlined by futurist Kenneth E. Boulding in a short essay in the Bulletin of the Atomic Scientists, "The Dodo didn't Make It: Survival and Betterment", published in 1971 (in a perennially well-named "Science And Society Symposium: Prospects For Survival" section). According to Boulding (cited in Gilder, 2014), there are eight "vectors of either appreciating or deteriorating change" that societies can follow (or not):

1. Consumption/production systems; 2. "Goods" and "bads" (with bads increasing due to informational overloads); 3. Joint production of goods and bads; 4. Invisible (externalities) by-products of intended 'goods" production; 5. Failures in the knowledge-generating and distribution process;

\footnotetext{
${ }^{1}$ Some preliminary work on these biological facts has been done by myself and Mervyn Hagger in the area of political philosophy.
} 
6. Knowledge pollution; 7. The growth of malevolent (versus benevolent) value systems; and, 8 . The payoff system (how are powerful people in the society paid, and from what area of the economy?) By walking through these eight vectors Boulding laid out the (r)evolutionary changes brought on by new technological drivers in our increasingly global society can be best revealed and described, and how certain social developmental niches that had worked well under one technological/economic system, came undone in the next. (p. 219)

As a "Silicon Valley" era thinker, Ken Wilber has written about integral psychology which is helpful in such a situation, in that it seeks to distinguish between pre- and post-psychological states and their corresponding and philosophical orientations (Gilder, 2008). As we move from one psychological stratum to another, we find, like Wittgenstein, that the epistemological ladders we needed to understand phenomena within a certain theoretical paradigm orientation become less useful as we transition to a new paradigm orientation. However, it does not follow that the knowledge and habits of mind we gained at the earlier stage become useless simply because they have been transcended, the modernist cloth merely needed to be refashioned for new purposes. Postmodernity correctly conceived is a needed critique of modernity, yet it requires modernity's presence to function. It is parasitical, and cannot live on its own. In this era of pandemic, we rely on the findings of modern science to save us. The playful pantomimes of postmodernity that entertained us in the shopping malls of late modernity can't do this, and it the wrong hands, it can even undo us (Horgan, 2020).

Wilber would say that naive postmodernists, who lacked the rigors of a modernist education, confuse the innocent perceptions of an infant to the wise perceptions of a Buddhist sage. The infant's 'pre-modern' perceptions are uncoloured by education and its biases, while the sage's 'post-modern' perceptions had been coloured by education and its biases; but she has had to learn to transcend them, but not forget their hard-earned lessons.

The New York Times columnist David Brooks has written about 'résumé values' versus 'eulogy values' (Brooks, 2015). What he means is that we spend a fair amount of our life and certainly the majority of our formal education concerned primarily with obtaining professional skills and mindsets better suited for our projected careers rather than in making us better persons. (This is an elaboration on the observation that nobody on their deathbed wishes they had spent more time at the office.) In today's pandemic, many nascent scholars are facing the possibility that higher 
education will be transformed by the brute necessities of the pandemic and their hoped-for careers in its imagined groves of learning taken away from them before they have even started on their first post. How should they (and we) refashion their work skills if many professional-level jobs, not just academic ones, disappear (Graeber, 2018) ${ }^{2}$ ?

Thus, even the humanities that have birthed the philosophy of postmodernity have to, contra Rosenau, take upon itself ethical responsibility. For example, if a literature teacher had convinced a student a few years ago to follow the life of a Po-Mo PhD scholarship, selling it as a viable (due to $\mathrm{PhD}$ program scholarships) and exciting life path (because of its intoxicating intellectual methodology), what does he now say to that student (who has committed time, mind and money) now that the scholarship and the career path disappear?

Brooks also speaks of the narratives that we tell ourselves and that give our lives meaning. Along this line of thought, Michel de Certeau refers to the 'recited Society', i.e., "our society has become a recited society, in three senses: it is defined by stories (récits, the fables constituted by our advertising and informational media), by citations of stories, and by the interminable recitation of stories" (1984, p. 186). Such life narratives are driven by our need to understand ourselves and the world around us in a hermeneutical way. In pre-modern times, humans sought to understand the text of the Bible, for example, both in original historical meaning and later ethical application. As Gadamer had noted, in hermeneutics, one seeks a "fusion of horizons" between a distant past and our present time (or between diverse persons in real time) (as cited by Malpas, 2018). We cannot travel back in time (or enter another person's mind), but we can bring the past (or the consciousness of another) into our own time or mind. In my view, scholars such as Gadamer sought to merge this pre-modern foundation into a methodology of modernity. Rhetorical scholars, such as

\footnotetext{
2 One thing that is clear is that the recently noted high-paid 'bullshit jobs' for companies making market promises will likely be no more. I sense the eulogy values will be more lasting and valuable for youth in this time to develop (Graeber, 2018).

${ }^{3}$ More dramatically, consider the movie "The Prime of Miss Jean Brodie": The protagonist is a charismatic and appealing teacher of teenage girls at a Scottish boarding school in the years following World War I. A protagonist who "lost" an idealized lover in the trenches of WWI, she regaled her students with romanticised stories of heroic battles in a ravishing fashion, making her very popular with her impressionable students. One vulnerable student in particular was moved by her stories to such an extent that she volunteered to go fight in the Spanish Civil War (on Franco's side), quickly losing her life thereby (Neame, 1969). So how one crafts and narrates these humanistic truth-claims can also have a strong effect on individual (and collective) lives with moral implications.
} 
Walter Fisher, introduced communication field to the narrative paradigm (Gilder, 2006). In so doing, he sought to integrate pathos with logos in creating a human actor (ethos) with a compelling story. But we need to recall that such life narratives are created after the fact in the mind of the person that re-constructs remembered events.

Recently, I had the opportunity in my habilitation thesis (Gilder, 2019), to tell the developmental narrative of my personal and professional ethos (re)creation over the last near three decades, and to opine about possible research directions. This pandemic did not occupy my mind such a short time ago!

In the 1980s I was a graduate student at the Ohio State University. My first area of intense study I was with dealing with communicative aspects of the AIDS crisis that was then ravaging the gay male community in the United States, leading to a solid publication that is still being cited decades later (Gilder, 1989; Kallings, 2008). Looking back, I know that if I had researched further on the topic, I would likely have had a solid academic career in the US, since I was one of the first researchers of the topic in my disciplinary area. But the emotional toll of that earlier pandemic was too great, so I changed my dissertation topic to an emotionally safer, if intellectually grander, proposed comparative study of Michael Foucault, Roland Barthes, Kenneth Burke and Wayne Booth. In the end, that bridging proposal was too ambitious in scope, so I settled on studying Wayne Booth alone. Even though I did consciously know it then, I ended up using the dissertation's philosophical foundation (constructive alternativism) and psychological methodology (personal construct psychology) to practice mental self-care. My psyche and soul had been ravaged by the AIDS crisis and I needed some mental help, but like my intellectual hero, Kenneth Burke, I found the writing cure better than the psychiatric one. ${ }^{4}$ In the end, I survived and (sort of) thrived, crafting an unexpectedly interesting transsectional and trans-continental career.

So now, decades later, I find myself reprising in an awkwardly similar fashion the same feeling of existential dread that I experienced in my $1980 \mathrm{~s}$ $\mathrm{PhD}$ days. I presently work in a technological university at the literal/figurative 'end of the world,' Papua New Guinea by name, that has (so far) escaped the blunt force of the virus, unlike Europe or the USA. But as in the movies "Jaws" (Shephard, 2020) and "On the Beach" (Gray, 2015),

\footnotetext{
${ }^{4}$ While in an intense psychological state, Burke had written a novel, Towards a Better Life (1966), because, as he put it, he was "too stubborn" to go to therapy. cf. Weiser, M.E., Horak, J.J. \& D. Monroe. JAC [Journal of Advanced Composition] 2007).
} 
the unseen danger nonetheless lurks as the shark did beneath the waves and the atomic cloud in the coming jetstreams. The virus is 'out there' and is (perhaps) coming for us soon (Bryant, 2020). Due to what I now see as God's grace (but often thought of at the time as a sorrowful missing of romance), I survived the AIDS pandemic unscathed. I pray I can survive this one, surely on its way to make its dreaded call to our under-prepared, underresourced shores (Kalolaine, 2020).

So, under such an appalling sword of Damocles, how can we use our knowledge to make precarious life in the time of COVID-19 'better' for our lived, networked communities as philosophers of whatever pre-, presentand post-flavour of modernity we claim (Kennedy, 2020) ${ }^{5}$ ? I believe each one of us needs to ask ourselves how one becomes what has been termed 'essential' workers of the mind in this foundation-turning age, in which the elaborated ideologies created by sophisticated wordsmiths of (post)modernity have been shown to be wanting, irrelevant, or downright harmful ${ }^{6}$. Naturally, people are first and foremost concerned with matters of biological survival and economic sustainability. To survive (and be seen as so deserving), postmodernity needs to find a functional foundation for its continuing existence, even as it has often denied this very foundation? ${ }^{7}$.

\section{References}

Arendt, H. (1998). The Human Condition (2nd ed.). Chicago \& London: University of Chicago Press.

\footnotetext{
5 The connection of the "networld' that spreads the virus (Kennedy, 2020).

6 "Post-modernism is not inherently left-wing or right-wing. Those who employ it, therefore, are not unconsciously subscribing to a political ideology along with it. But this reassurance should not be too comforting. It does not signal political neutrality. It may only indicate that post-modernity is so abstract and obscurantist that it can be manipulated to fit any political orientation" (Rosenau, 1992, p. 166). As de Certeau states: "Narrations about what's-going-on constitute our orthodoxy. Debates about figures are our theological wars. The combatants no longer bear the arms of any offensive or defensive idea. They move forward camouflaged as facts, data and events. They present themselves as messengers from a 'reality.' Their uniform takes on the color of the economic and social ground they move into. When they advance, the terrain itself seems to advance. But, in fact they fabricate the terrain, simulate it, use it as a mask, accredit themselves by it, and thus create the scene of their law" (1984, pp.185-186).

7 I recommend two sets of 'real time' writings in this time of stress: First, colleagues at the "Ion I.C. Brătianu" Institute of Political Science and International Relations at Romanian Academy have been publishing an online Academic Journal in a Time of Crisis has much to recommend it as a work of useable praxis. Second, Rod Dreher of The American Conservative magazine has been publishing a series of "Pandemic Dairies" on his blog. I contributed an entry in number 22 of the series (2020).
} 
Booth, W. C. (1988). The Company We Keep: An Ethics of Fiction. Berkeley: University of California Press.

Boulding, K. E. (1971). The Dodo didn't Make It: Survival and Betterment. Bulletin of the Atomic Scientists (May 1971), 19-22.

Brooks, D. (2015, April 11). The Moral Bucket List. The New York Times. https://www.nytimes.com/2015/04/12/opinion/sunday/david-brooksthe-moral-bucket-list.html

Bryant, A. (2020). IB 2020/06 Coronavirus Covid-19 in Papua New Guinea. In Brief 2020/6. Department of Public Affairs, Australian National University. http://dpa.bellschool.anu.edu.au/sites/default/files/publications/attachm ents/2020-03/dpa in brief 20206 allen covid-19.pdf

Burke, K. (1966). Towards a Better Life. Berkeley: University of California Press.

Certeau, M. (1984). The Practice of Everyday Life (S. Rendall, Trans.). Berkeley: University of California Press.

Dreher, R. (2020, April 7). Pandemic Dairies 22. The American Conservative. https://www.theamericanconservative.com/dreher/pandemic-diaries-22/

Gilder, E. (1989). The Process of Political Praxis: Efforts of the Gay Community to Transform the Social Signification of AIDS. Communication Quarterly, 37(1) 27-38.

Gilder, E. (1997). Bibliographical References: Book Reviews. Higher Education in Europe, 22(2), 257-258.

Gilder, E. (2006). Four Views of Rhetorical Knowing in the Knowledge Based Organization. In Proceedings of the 11th Scientific Communication Section, Vol. 11 "Man in the Knowledge Based Organization" (pp. 7-14). Sibiu: Land Forces Academy Publishing House.

Gilder, E. (2008). Integral Psychology: Consciousness, Spirit, Psychology, Therapy, by Ken Wilber. Boston \& London: Shambhala, 2000, xiii + 303 pp. ISBN 1-57062-554-1 (Review). "Book Reviews and Studies" Higher Education in Europe, 33(1) 183-191.

Gilder, E. (2014). Technological Drivers of (R)evolutionary Change in Modern Societies and How Developing Countries Might Productively Respond to Them via Intentional, Thoughtful 'Leapfrogging'. In Proceedings of the 7th2013 Huon Conference, PNG University of Technology, Lae, November 13-14, 2013 (pp. 218-226). Lae: The Papua New Guinea University of Technology.

Gilder, E. (2019). Rhetorics in English Literary and Non-Literary Discourse -- Professing Rhetrorics in English-Language Literary and Non-Literary Discourse: Life, Logos and Practices across Selves, Time and Space (English Philology) [Unpublished Habilitation Thesis]. Sibiu: Lucian Blaga University.

Gilder, E., \& Hagger, M. (2012). 'Me and my Shadow' Reinterpreted: Collectivism Applied to Individualism as a Stereoscopic Overlay Producing an Illusion 
Towards a Post-Pandemic Postmodern Society - Is the Pandemic a ... Eric GILDER

of Reality. (M)OTHER NATURE? Inscriptions, Locations, Revolutions, II(2), 20-28.

Graeber, D. (2018). Bullshit Jobs: A Theory. New York: Simon \& Schuster.

Gray, B. (2015, August 3). The Continuing Relevance of 'On the Beach. Bulletin of the Atomic Scientists. https://thebulletin.org/2015/08/the-continuingrelevance-of-on-the-beach/

Hahn, L., Lippet, L., \& Paynton, S.T. (2014). Communication Research. In Survey of Communication Study (pp. 70-71).

https://www.csus.edu/indiv/s/stonerm/ComS5SurveyOfCommunication Textbook.pdf.

Horgan, J. (2020, March 9). The Coronavirus and Right-Wing Postmodernism. Scientific American. https://blogs.scientificamerican.com/cross-check/thecoronavirus-and-right-wing-postmodernism/ .

Jameson, F. (1991). Postmodernism, or, the Cultural Logic of Late Capitalism. Durham [NC]: Duke University Press.

Kalantzis, M., \& Cope, B. (2020, April 26). Matthew Arnold on Learning 'The Best Which Has Been Thought and Said. Works \& Days.

https://newlearningonline.com/new-learning/chapter-7/matthew-arnoldon-learning-the-best-which-has-been-thought-and-said .

Kallings, L. O. (2008). The First Postmodern Pandemic: 25 years of HIV /AIDS. Journal of Internal Medicine, 263, 218-243.

Kalolaine, F. (2020, April 11). 'We Have Nothing': Papua New Guinea's Broken Health System Braces for Covid-19. The Pacific Report. The Guardian. https://www.theguardian.com/world/2020/apr/11/we-have-nothingpapua-new-guineas-broken-health-system-braces-for-covid-19 .

Kellner, D. (2003). "Jacques Baudrillard," The Blackwell Companion to Major Contemporary Social Theorists (George Ritzer, ed.). Blackwell (pp. 310-32).

Kennedy, M. (2020, March 21). "Historian Niall Ferguson Warns of Contagion, Online and Off." $A B C$ News.

https://abcnews.go.com/Entertainment/wireStory/historian-niallferguson-warns-contagion-online-off-69709677.

Malpas, J. (2018). Hans-Georg Gadamer. In E. N. Zalta (Ed.), The Stanford Encyclopedia of Philosophy.

https://plato.stanford.edu/archives/fall2018/entries/gadamer/

Maslow, A. H. (1943). A Theory of Human Motivation. Reprinted in "Classics in the History of Psychology”, internet resource by C. D. Green. University of Toronto. http://psychclassics.yorku.ca/Maslow/motivation.htm .

Neame, R. (Director). (1969). The Prime of Miss Jean Brodie [Film]. 20th Century Fox

Rosenau, M.P. (1992). Postmodernism and the Social Sciences: Insights, Inroads, and Intrusions. Princeton [NJ]: Princeton University Press. 
Shephard, A. (2020, March 20). The Pandemic Movie of our Time isn't Contagion. It's Jaws. The New Republic.

https://newrepublic.com/article/156991/pandemic-movie-time-isntcontagion-its-jaws 